\title{
MEDIA UTILISATION AMONG SECONDARY TRAINEE TEACHERS IN THEIR TEACHING-LEARNING ACTIVITIES
}

\author{
Dr. R. Ramesh *1凶 \\ ${ }^{* 1}$ Associate Professor, Department of Education, Periyar University, Salem-636011, Tamil Nadu, \\ India
}

DOI: https://doi.org/10.29121/granthaalayah.v9.i2.2021.3629

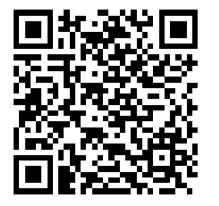

Article Type: Research Article

Article Citation: Dr. R. Ramesh. (2021). MEDIA UTILISATION AMONG SECONDARY TRAINEE TEACHERS IN THEIR TEACHINGLEARNING ACTIVITIES. International Journal of Research GRANTHAALAYAH, 9(2), 275-280. https://doi.org/10.29121/granthaa layah.v9.i2.2021.3629

Received Date: 25 January 2021

Accepted Date: 27 February 2021

Keywords:

Secondary Teacher Education Trainee Teachers

Media Utilisation

\begin{abstract}
This study explored the views of teacher trainees on various components of their training about the use of new technology to teach their subject. There is a significant change in our daily life with the advancement of information and communication technologies. Integrating ICTs into teaching and learning offers significant potentials for higher education institutions and opens new challenges for educators, through their capacity to facilitate new kind of education in the digital environment. Particularly, the use of technology in teacher education opens new opportunities for teachers and students. The success of ICT in teacher education depends on teacher educators, trainee teachers and authorities in the institutions. The present study investigated the media utilisation among secondary trainee teachers in their teaching-learning activities. The investigator adopted the survey method and used random sampling technique for the selection of sample. A structured questionnaire was distributed to the selected 500 teacher-trainees and data collected were analyzed using t-test. The findings concluded that the selected personal variables like sex, locality of the students, type of institutions and locality of the institutions have influenced media utilisation among secondary trainee teachers in their teaching-learning activities.
\end{abstract}

\section{INTRODUCTION}

The rapid advancement of information and communication technology (ICT) has brought a revolutionary change in the information scenario giving rise to a number of options to handle varied information sources conveniently. The modern educational technology is now capable of becoming a major resource for the delivery of educational services in most parts of our country. This is so because modern educational technology provides capabilities for responding to new demands that traditional classroom education cannot meet adequately (Wang, 2009). It has been shown that in comparison to traditional classrooms, technology supported classrooms have the potential to improve instructions (Idayavani \& Shanthi, 2003). It is, therefore, need to use educational technologies in forms of audio (Radio, Tape Recorder etc.), visual (Projected; Transparencies, Slides etc. and Non-projected; Charts, Models etc.) and audio-video (Television, Computers and Multimedia systems etc.) in teaching and learning. Using technology in classrooms can greatly enhance the efficacy of students' learning and academic achievement. The accessibility of technology has been rapidly increasing throughout the recent years.

ICT has changed the scenario of teacher education and going to add more change in the system. It is also stated in the National Curriculum Framework for School Teacher Education (2005). Changes in the perception of 'learning

(C) 2021 The Author(s). This is an open access article distributed under the terms of the Creative Commons Attribution License, which permits unrestricted use, distribution, and reproduction in any medium, provided the original author and source are credited. 
environment' have been highlighted by National Curriculum Framework (2000), which seek to exploit the potential of ICT. The National Curriculum Framework has emphasized on the utilization of ICT in teacher education institutions (Ratan \& Vijayakumar,2016). The success of ICT in teacher education depends on teacher educators, student-teachers and authorities in the institutions. The use of technology in teacher education opens new opportunities for teachers and students. Teacher educators can be considered important stakeholders who prepare and motivate a new generation of teachers for teaching in today's classrooms. They can also play a key role in enhancing preservice teachers' technology enhanced educational practices. Consequently, preparing future teachers to integrate technology in their educational practice is a challenge that teacher educators are increasingly confronted with it (Liu, 2016; Ping et al., 2018).

The trainee teachers are future teachers and it is their responsibility to maintain the quality of teachinglearning. In the modern world, media role is significant in supporting instructional activities. Now, it is the time to aware that the teacher trainees are competent enough to utilize the instructional media for their transactional purposes. This study explored the views of teacher trainees on various components of their training about the wise use of new technology to teach their subject. In the present, the investigator analysed the media employment in teaching-learning among secondary trainee teachers in five factors viz.,

(i) preparing practical records and assignments, (ii) micro and macro teaching practice, (iii) self-learning, (iv) doing projects, action research and case studies and (v) group activities.

\section{OBJECTIVES}

1) To find out the extent of media utilisation among secondary trainee teachers in their teaching-learning activities.

2) To find out the media utilisation among secondary trainee teachers in their teaching-learning activities with respect to sex, age, marital status, locality of the students, type of the institutions, locality of the institutions and medium of instruction.

\section{HYPOTHESES}

1) There will be a significant mean score difference in media utilisation among secondary trainee teachers in their teaching-learning activities with respect to sex.

2) There will be a significant mean score difference in media utilisation among secondary trainee teachers in their teaching-learning activities with respect to age.

3) There will be a significant mean score difference in media utilisation among secondary trainee teachers in their teaching-learning activities with respect to marital status.

4) There will be a significant mean score difference in media utilisation among secondary trainee teachers in their teaching-learning activities with respect to locality of the students.

5) There will be a significant mean score difference in media utilisation among secondary trainee teachers in their teaching-learning activities with respect to type of the institutions.

6) There will be a significant mean score difference in media utilisation among secondary trainee teachers in their teaching-learning activities with respect to locality of the institutions.

7) There will be a significant mean score difference in media utilisation among secondary trainee teachers in their teaching-learning activities with respect to medium of instruction.

\section{RESEARCH DESIGN}

In order to realize the aforesaid objectives and hypotheses, the survey method is employed for the present study. A total of 500 trainee teachers from government and private college of education were selected as a sample for this study. The simple random sampling procedure was adopted. The data were collected from the selected samples using a self-made Questionnaire on Media Utilisation in Teaching-Learning. The investigator used t-test to analyze the data and summarized the results. 


\section{RESULTS AND DISCUSSION}

\subsection{HYPOTHESES TESTING}

\subsubsection{HYPOTHESIS-1}

There will be a significant mean score difference in media utilisation among secondary trainee teachers in their teaching-learning activities with respect to sex

Table 1: Mean score difference in media utilisation among secondary trainee teachers in their teachinglearning activities with respect to sex

\begin{tabular}{|c|c|c|c|c|c|c|}
\hline Sex & $\mathrm{N}$ & $\mathrm{M}$ & $\mathrm{S} . \mathrm{D}$ & $\mathrm{df}$ & t value & P value \\
\hline Male & 119 & 71.65 & 8.90 & \multirow{2}{*}{498} & \multirow{2}{*}{2.99} & \multirow{2}{*}{.002} \\
\hline Female & 381 & 68.91 & 8.14 & & & \\
\hline
\end{tabular}

Table- 1 shows the significant mean score difference between male and female secondary trainee teachers in media utilisation in their teaching-learning. The calculated ' $t$ ' value is significant at 0.05 level. So the hypothesis- 1 is accepted. Further, the male trainees are better than the female in media utilisation in teaching-learning.

\subsubsection{HYPOTHESIS - 2}

There will be a significant mean score difference in media utilisation among secondary trainee teachers in their teaching-learning activities with respect to age

Table 2: Mean score difference in media utilisation among secondary trainee teachers in their teachinglearning activities with respect to age

\begin{tabular}{|c|c|c|c|c|c|c|}
\hline Age & $\mathrm{N}$ & $\mathrm{M}$ & S.D & df & T value & P value \\
\hline Upto 25 years & 430 & 69.43 & 8.35 & 498 & 0.83 & .406 \\
\cline { 1 - 5 } Above 25 years & 70 & 70.37 & 8.74 & & & \\
\hline
\end{tabular}

According to the Table-2 mean score difference between secondary trainee teachers in media utilisation in teaching-learning with respect to their age. But it is statistically not significant at 0.05 . So, the hypothesis- 2 is rejected. Further it is concluded that the age does not influence the secondary teacher trainees in media utilisation.

\subsubsection{HYPOTHESIS-3}

There will be a significant mean score difference in media utilisation among secondary trainee teachers in their teaching-learning activities with respect to marital status

Table 3: Mean score difference in media utilisation among secondary trainee teachers in their teachinglearning activities with respect to marital status

\begin{tabular}{|c|c|c|c|c|c|c|}
\hline Marital Status & $\mathrm{N}$ & $\mathrm{M}$ & $\mathrm{S} . \mathrm{D}$ & $\mathrm{df}$ & $\mathrm{T}$ value & P value \\
\hline Married & 122 & 69.18 & 7.67 & 498 & 0.61 & .542 \\
\cline { 1 - 5 } Unmarried & 378 & 69.69 & 8.63 & & & \\
\hline
\end{tabular}

Table 3 reveals that statistically there is no significant difference in utilisation of media among secondary trainee teachers. Hence the hypothesis- 3 is rejected. This finding inferred that the marital status does not influence the media employment in teaching and learning. 


\subsubsection{HYPOTHESIS - 4}

There will be a significant mean score difference in media utilisation among secondary trainee teachers in their teaching-learning activities with respect to locality of the students

Table 4: Mean score difference in media utilisation among secondary trainee teachers in their teachinglearning activities with respect to locality of the students

\begin{tabular}{|c|c|c|c|c|c|c|}
\hline Locality of Students & N & M & S.D & df & $\begin{array}{c}\text { t } \\
\text { value }\end{array}$ & $\begin{array}{c}\text { P } \\
\text { value }\end{array}$ \\
\hline Rural & 380 & 68.49 & 7.97 & 498 & 4.94 & .000 \\
\hline Urban & 120 & 72.96 & 8.84 & & & \\
\hline
\end{tabular}

From the Table- 4 there is a mean score difference between rural and urban based secondary trainee teachers in media utilisation in teaching learning. The calculated $t$-value is significant at 0.05 level. Hence the hypothesis-4 is accepted. It is also concluded that the urban based secondary teacher trainees are better in utilisation of media for their teaching-learning than their counter part.

\subsubsection{HYPOTHESIS - 5}

There will be a significant mean score difference in media utilisation among secondary trainee teachers in their teaching-learning activities with respect to type of the institutions

Table 5: Mean score difference in media utilisation among secondary trainee teachers in their teachinglearning activities with respect to type of the institutions

\begin{tabular}{|c|c|c|c|c|c|c|}
\hline Type of Institutional & $\mathrm{N}$ & $\mathrm{M}$ & $\mathrm{S} . \mathrm{D}$ & $\mathrm{df}$ & $\begin{array}{c}\mathrm{t} \\
\text { value }\end{array}$ & $\begin{array}{c}\mathrm{P} \\
\text { value }\end{array}$ \\
\hline Government & 82 & 77.43 & 5.60 & 498 & 12.86 & .000 \\
\hline Private & 418 & 68.02 & 7.99 & & & \\
\hline
\end{tabular}

From Table-5 it is clear that there is significant mean score difference in media utilisation among secondary trainee teachers in their teaching-learning activities with respect to type of the institutions. It is statistically significant at 0.05 level. So, the hypothesis- 5 is accepted. Further it is revealed that the government college trainee teachers are better in media utilisation in their teaching-learning.

\subsubsection{HYPOTHESIS - 6}

There will be a significant mean score difference in media utilisation among secondary trainee teachers in their teaching-learning activities with respect to locality of the institutions

Table 6: Mean score difference in media utilisation among secondary trainee teachers in their teachinglearning activities with respect to locality of the institutions

\begin{tabular}{|c|c|c|c|c|c|c|}
\hline Locality of Institution & N & M & S.D & df & $\begin{array}{c}t \\
\text { value }\end{array}$ & $\begin{array}{c}p \\
\text { value }\end{array}$ \\
\hline Rural & 418 & 69.13 & 8.24 & 498 & 2.47 & .013 \\
\hline Urban & 82 & 71.76 & 8.91 & & & \\
\hline
\end{tabular}

It is evident from table- 6 there is a mean score difference in media utilisation among secondary trainee teachers in their teaching-learning activities with respect to locality of the institutions. It is statistically significant at 0.05 level. So, the hypothesis- 6 is accepted. It is also concluded that the locality of the institutions has influenced the media utilisation among secondary trainee teachers in their teaching-learning activities. 


\subsubsection{HYPOTHESIS - 7}

There will be a significant mean score difference in media utilisation among secondary trainee teachers in their teaching-learning activities with respect to medium of instruction

Table 7: Mean score difference in media utilisation among secondary trainee teachers in their teachinglearning activities with respect to medium of instruction

\begin{tabular}{|c|c|c|c|c|c|c|}
\hline Medium of Institution & $\mathrm{N}$ & $\mathrm{M}$ & S.D & $\mathrm{df}$ & $\begin{array}{c}\mathrm{t} \\
\text { value }\end{array}$ & $\begin{array}{c}\mathrm{P} \\
\text { value }\end{array}$ \\
\hline Tamil & 314 & 69.24 & 8.29 & 498 & 1.09 & .276 \\
\hline English & 186 & 70.10 & 8.58 & & & \\
\hline
\end{tabular}

Table-7 presents the mean score difference in media utilisation among secondary trainee teachers in their teaching-learning activities with respect to medium of instruction. But the difference is statistically not significant at 0.05 level. So the hypothesis No.7 is rejected. The findings inferred that the medium of instruction does not influence the media utilisation among secondary trainee teachers.

\section{CONCLUSIONS}

Considering the results and findings of the present study, it is concluded that the selected personal variables such as sex, locality of the students, type of institution and locality of the institutions have influenced the media utilisation among secondary trainee teachers in their teaching-learning activities. The remaining variables such as age, marital status and medium of instruction does not influence the secondary trainee teachers in utilisation of media in teaching and learning.

\section{RECOMMENDATIONS}

1) The present study recommends the directorate of collegiate education to organize in-service training programme for teacher educators on effective utilisation of various media and ICT tools for teachinglearning. It is useful to train the future teachers.

2) The college administration should permit the teacher trainees to attend workshop and training programme related to ICT.

3) The present study recommends the college administration to provide adequate resources to the trainees for preparing media materials in their own subjects.

4) The study further recommends the school administration to encourage the trainee teachers to use media materials during the time of their teaching practice.

\section{SOURCES OF FUNDING}

This research received no specific grant from any funding agency in the public, commercial, or not-for-profit sectors.

\section{CONFLICT OF INTEREST}

The author have declared that no competing interests exist.

\section{ACKNOWLEDGMENT}

None. 


\section{REFERENCES}

[1] Idayavani, D. \& Shanthi, S. (2003). Impact of video assisted instructions in schools. The Educational Review, 46 (7), 19-23.

[2] Liu, P. (2016). Technology integration in elementary classrooms: Teaching practices of student teachers. Australian Journal of Teacher Education, 41(3), 87-104.

[3] Ping, C., Schellings, G. \& Beijaard, D. (2018). Teacher educators' professional learning: A literature review. Teaching and Teacher Education, 75, 93-104.

[4] Ratan, C., \& Vijayakumar, E. (2016). A study of ICT awareness, need and usage among teacher educators of B.Ed. colleges of Hyderabad. International journal of informative \& futuristic research, 4(2), 5072-5081.

[5] Wang, C. (2009). The Open Access Advantage Considering Citation, Article Usage and Social Media Attention, Humanities and Social Sciences, Dalian University of Technology, Dalian 116085, China. Retrieved fromihttps://wiki.lib.sun.ac.za/images/6/6b/1503.05702 